\title{
Educación y relaciones de poder en una comunidad toba del Chaco argentino ${ }^{1}$
}

LORENA CARDIN ${ }^{2}$

\section{RESUMEN}

A partir del análisis de la dinámica escolar de una "Colonia Aborigen" toba en el este de la provincia de Formosa, el trabajo se centra en el estudio de las causas de la deserción escolar sobre todo en el Nivel Polimodal ${ }^{3}$ y en las respuestas, estrategias y medidas que la comunidad educativa local toma, atendiendo a las relaciones de fuerza entre sus miembros de distintas posiciones sociales. Se seguirá la propuesta de Bourdieu sobre la necesidad de una "perspectiva relacional" para evitar comprender el mundo social desde una mirada "sustancialista".

Palabras claves: deserción escolar - "campo de poder"4 - estrategias - toba.

\section{ABSTRACT}

With the analyses of a Toba "aboriginal community" school dynamics (East of Formosa Province) as a starting point, this research is focused on the study of the causes of school dropout, especially at the Polimodal level, and on the answers, strategies and measures that were taken by the local educational community in accordance with the power relationships resulting from their members' social positions. Bourdieu's proposal on the need of a "relational perspective" will be followed, in order to avoid understanding the social world from a "substantialist" point of view.

Key words: school dropout - "field of power" - strategies - Toba

Recibido: marzo 2003. Manuscrito revisado aceptado: agosto 2003.

1 Una versión preliminar de este trabajo fue presentada en las I Jornadas "Experiencias de la Diversidad" del Centro de Estudios sobre Diversidad Cultural de la Universidad Nacional de Rosario, Rosario, mayo de 2003.

2 Universidad de Buenos Aires. Dirección particular: Guatemala $47307^{\circ}$ "D", C. P. 1425, Buenos Aires. Email: mmederenal@hotmail.com

3 En 1994 la Ley Federal de Educación estableció una nueva estructura del sistema educativo argentino. La Educación Inicial (niños hasta cinco años), la Educación General Básica (E.G.B.) obligatoria con una duración de nueve años a partir de los seis años de edad y la Educación Polimodal que dura tres años. Cada vez que se utilice el término "escuela" se estará haciendo referencia a la Educación General Básica y con el nombre de Colegio a la Educación Polimodal.

\section{Introducción $^{5}$}

Los aborígenes ${ }^{6}$ toba constituyen un grupo étnico de lengua guaycurú que habita en la región chaqueña al nordeste del país, actualmente son unas 40.000 personas aproximadamente (Figura 1). Su modo de subsistencia fue la caza y la recolección y una vida nómade hasta que las campañas del ejército argentino pusieron fin a su estilo de vida. Iniciaron entonces un proceso de sedentarización y transformación de su modo de producción. ${ }^{7}$

Actualmente estas poblaciones se dedican a tareas agrícolas, artesanales, a trabajos temporarios como cosecheros, de algodón principalmente, o como peones en estancias de la población blanca y, en menor medida, a la caza y recolección, debido a la reducción de tierras libres. En el caso concreto de la población mencionada, este proceso de sedentarización estuvo unido a la presencia de misiones religiosas. A finales de la década del '30, la zona comenzó a recibir la influencia de misioneros evangélicos y en los '60 se formaron

4 Bourdieu emplea el concepto de "campo de poder" en reemplazo del concepto de clase dominante, entendiendo al primero como "relaciones de fuerza entre las posiciones sociales que garantizan a sus ocupantes un quantum suficiente de fuerza social -o capital- para que estén en condiciones de participar en las luchas por el monopolio del poder (...)" (Bourdieu y Wacquant 1995: 171). La existencia de un capital común y la lucha por su apropiación son sus elementos constitutivos.

5 Por cuestiones laborales viajé a la zona durante el receso escolar, y presencié el funcionamiento del servicio del comedor. En dicho momento acudían a la escuela: los alumnos, al menos un maestro o director, la cocinera, el sereno y muchos padres y madres cumpliendo sus tareas de mantenimiento y en la cocina dentro del plan asistencial denominado "Plan Trabajar".

6 A lo largo del trabajo, empleo las categorías sociales "aborigen" y "criollo", pues son los propios residentes de la comunidad quienes las usan para identificarse y distinguirse de los no aborígenes.

7 Hugo Trinchero (2000) analiza las características e impacto de las campañas militares y de las misiones religiosas en la zona. 


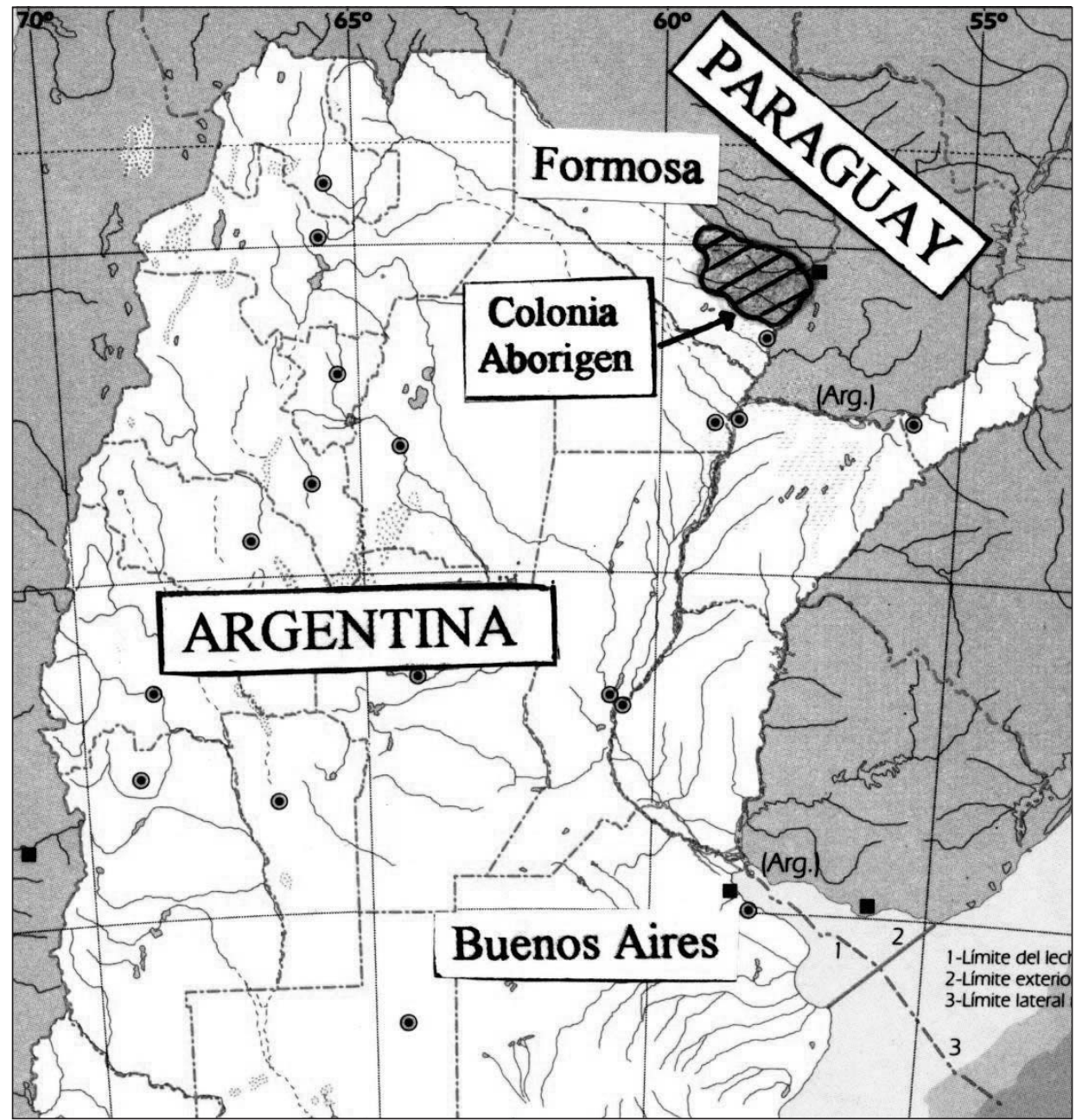

Figura 1. Ubicación de la Colonia Aborigen toba, en la provincia de Formosa, Argentina.

las primeras iglesias aborígenes con influencias pentecostales identificadas con el nombre genérico de "evangelio". 8

A su vez, la ayuda asistencial estatal constituye un factor necesario para la población aborigen aunque el arribo de dicha ayuda social es irregular y cada vez más exiguo, dependiendo la misma de la burocracia política, de las "relaciones clientelares"9 y de la proximidad de épocas electorales.

La comunidad en la que trabajé cuenta aproximadamente con más de dos mil habitantes distri-

8 Los autores Miller (1979), Cordeu (1984), Wright (1988 y 1990) y Citro (2001) han trabajado sobre la religión y las Iglesias toba.

9 El partido Justicialista gobierna la provincia desde 1983. Este solventa con sueldo, "mercaderías" (alimentos sobre todo) y "favores personales" (medicamentos, trámites por buidos en cinco mil hectáreas de tierras. Es una zona fronteriza con Paraguay, existiendo un movimiento migratorio intenso entre ambos países. Como característica particular de la región se destaca su multilingüismo (toba-castellano-guaraní). Dentro de la colonia existen tres escuelas, a las que denominaré arbitrariamente A, B y C, y sólo una en el pueblo vecino a la que me referiré como la escuela D. ${ }^{10}$ En dicho pueblo existe un solo Colegio Polimodal.

pensiones, etc.) a "dirigentes" del partido, los cuales, a su vez, reparten estos bienes y favores entre los miembros del asentamiento, especialmente a través de las redes de parentesco y los mecanismos de reciprocidad.

$10 \mathrm{He}$ optado por reservar la identidad tanto de las escuelas como de las personas con el objetivo de evitar comprometerlos o perjudicarlos con la publicación de este trabajo. 
Pude observar una clara distinción entre dos zonas denominadas El Cruce y El Fondo cuyas características particulares se verán reflejadas, por un lado, en cómo impactan los condicionantes estructurales en cada una y, por el otro, en las diferencias estratégicas de los habitantes de ambas. En el primer caso, debido a su cercanía con el asfalto y con el pueblo, las familias que ahí habitan y la escuela B mantienen una interrelación estrecha con los criollos de la zona. Los beneficios de su estratégica ubicación son múltiples. La mayoría de dichas familias han viajado mucho, incluso han mantenido una vida con muchos desplazamientos viviendo temporalmente en las ciudades de Clorinda, Formosa capital, Asunción y en otras Colonias vecinas. Los pocos jóvenes toba que han terminado el Polimodal pertenecen a dichas familias y las casas que cuentan con el servicio eléctrico también se encuentran ahí. En contraste, las familias y la escuela $\mathrm{C}$ que se ubican en El Fondo se ven muy desfavorecidas. Su distancia respecto de El Cruce de rutas es de $8 \mathrm{~km}$ y debido al pésimo estado de los caminos de tierra, cuando llueve suele quedar aislada.

\section{Red de factores que obstaculizan la escolarización ${ }^{11}$}

A través de las diversas conversaciones que mantuve con miembros de la comunidad educativa de la zona, profesores, maestros, padres y alumnos, advertí que todos coincidían en un punto: los niños toba en su mayoría no ingresan o abandonan el Polimodal. En un apartado del Proyecto E.G.B. $3^{12}$, que presentó la directora de la escuela B en 1999, intitulado "Diagnóstico Educativo" se afirma:

"Se considera, además, que los alumnos al culminar la escuela primaria, en su mayoría no asisten a la escuela del Polimodal y polimodal y los

11 Si bien se analizarán los factores externos que impiden la regular asistencia de los niños toba a la escuela, es imprescindible reconocer también aquellos elementos propios de su especificidad sociocultural que pueden producir el mismo efecto, como ser la libertad con que los niños toba son criados en sus casas y la ausencia de una autoridad familiar coercitiva que los compele a asistir diariamente a clase.

12 Proyecto por el cual se pide a las autoridades educativas la aprobación y los fondos necesarios para dictar clases para los tres años del $3^{\text {er }}$ ciclo de la Escuela General Básica. Hasta ese momento se dictaba en la escuela sólo hasta $7^{\circ}$ año, pero la Ley Federal de Educación incluyó también al $8^{\circ}$ y $9^{\circ}$ año dentro del último ciclo de la E.G. B. que asisten quedan desgranados en los primeros años de haber ingresado. Tomada como muestra la vida institucional del Colegio del pueblo con 21 años de servicio educativo, en cuyo período pudieron concluir sus estudios de educación media, dos aborígenes sobre un total de 32 aborígenes que habian iniciado sus estudios (...)".

Faustina, profesora de lengua del Colegio, me comentaba que son muy pocos los niños aborígenes que asisten a dicha institución actualmente, de 580 alumnos sólo tres o cuatro son aborígenes. Este año se incorporará la primera camada de alumnos provenientes de la E.G.B. 3 rural y se calcula que ingresarán 19 alumnos aborígenes de los cuales entre nueve y 11 se encontrarían en "buenas condiciones", me decía.

Cuando les pregunté a las madres que se encontraban en la escuela $\mathrm{C}$, cuál les parecía que era la razón de la deserción escolar, me comentaron que los niños en dicha escuela finalizan $7^{\circ}$ grado sin saber hablar castellano y que no quieren seguir estudiando pues les da "vergüenza".

Sobre este punto surgen dos cuestionamientos, por un lado cómo un niño que no ha aprendido la lengua castellana puede egresar de una escuela y por el otro por qué luego de siete años de escolarización un niño no aprende a hablar dicho idioma.

La respuesta a la primera pregunta me la brindaron los maestros y directoras cuando me explicaron el sistema de clasificación de las distintas escuelas. Depende de la cantidad de cursos (secciones) que una escuela tenga, el grado de "complejidad" que a la misma se le adjudica, si este llegara a descender porque se cerrasen cursos entonces la escuela perdería algunos cargos. ${ }^{13}$

Los maestros de la escuela B me explicaban que si ellos hicieran repetir a los niños que consideran que se encuentran por debajo del nivel de pro-

\footnotetext{
13 Por ejemplo en la escuela D del pueblo sus 700 alumnos se distribuyen en 23 secciones de la E.G.B. y 4 del Nivel Inicial correspondiéndole una complejidad de grado cuatro. La escuela B cuenta con 294 alumnos y 12 secciones, su complejidad es de grado tres. A la escuela A asisten 103 alumnos siendo su complejidad de grado dos con cuatro secciones, y finalmente la escuela $\mathrm{C}$ con 150 alumnos, siete secciones y complejidad también de grado dos.
} 
moción, dos cursos quedarían vacíos y se cerrarían. Si ello ocurriera el grado de complejidad bajaría a dos, porque la escuela pasaría a contar con menos de 11 secciones. En dicho caso se perderían el cargo de vicedirectora, el de dos maestros y el del portero.

"Son los blancos los que nos salvan", afirmaba una maestra, "pues ellos generalmente aprueban, el problema mayor lo tiene la escuela $\mathrm{C}$ que no cuenta con niños criollos y por ello llegan a $7^{\circ}$ con muchos problemas".

Un profesor de geografía y biología de un pueblo criollo cercano a otra Colonia, a quien conocí en mi anterior viaje me había dicho lo mismo:

“(...) los maestros aprueban a los niños para que no les cierren un aula y entonces les paguen menos. Los chicos entonces llegan al secundario escribiendo hormiga sin ' $h$ '”.

Existe otro recurso empleado por los maestros cuando los niños faltan mucho. Ellos van a buscarlos a sus casas y les consiguen ropa, zapatillas $\mathrm{y}$ útiles. Si bien ha de haber una cuota de preocupación porque los niños finalicen su escolarización, además del afecto de los docentes hacia sus alumnos, también es cierto, según los propios maestros, que debido al mecanismo de categorización escolar descrito, se establece entre las escuelas una competencia por seducir y reclutar alumnos.

Más allá de que los niños tengan mayor o menor competencia lingüística, el nivel en general de los egresados de las escuelas del asentamiento es por debajo de la exigencia mínima del Colegio. La misma profesora afirmaba que la gran mayoría de los niños aborígenes repite el $8^{\circ}$ año y que existe una gran diferencia de nivel entre la escuela del pueblo y las de la Colonia. Cuando, cuatro años atrás, el Colegio Polimodal envió los contenidos mínimos que debía poseer un alumno para ingresar a dicha institución, sólo la escuela $\mathrm{D}$ del pueblo pudo elevar significativamente su nivel académico.

Los diagnósticos de los primeros cursos del Colegio Polimodal confirman, según su bibliotecario, la diferencia de nivel a la que hizo referencia la profesora. Los maestros y directores de las escuelas aborígenes coinciden que nunca se dan to- dos los contenidos y que priorizan las áreas de Lengua y Matemática. Además reconocen que la lecto-escritura les lleva mucho tiempo.

Los niños reconocen su mal manejo de la lengua oficial y por "vergüenza" se autocensuran y callan. Tal es el caso de los alumnos de la escuela $\mathrm{C}$ que no se "animaron" a cursar el $8^{\circ}$ año. Son las leyes del mercado las que los condenan al silencio en las situaciones oficiales. Oscar, el bibliotecario, me comentaba que cuando Silvia, alumna aborigen que cursa $9^{\circ}$ año, va a retirar un libro, siempre espera que los jóvenes criollos sean atendidos primero para luego acercarse a él y hacerle su pedido. La profesora de lengua también me relataba, a su vez, que cuando ella les consulta si entendieron todo o si quieren hacerle alguna pregunta, los jóvenes aborígenes nunca le responden ni le piden ayuda, pero sí asisten a los talleres de apoyo que se dictan fuera del horario de clases. Los maestros, generalmente, consideran al "silencio toba" como "una actitud propia de su cultura". ${ }^{14}$

Pasemos a analizar a continuación el segundo de los interrogantes planteados. Diversas teorías han intentado explicar el fracaso escolar de las minorías, en este sentido considero que deben tenerse en cuenta una "red de factores". En primer término, se analizará la falta de medios de la comunidad para "invertir" en la educación de sus hijos y de las escuelas para poder sostener su nivel educativo y mantener sus instalaciones. Con respecto al grado de pauperización de la Colonia, si bien no se observan casos de desnutrición debido a la fertilidad de la tierra, la asistencia sanitaria es prácticamente nula. Existen casos de tuberculosis, no hay medicamentos en los hospitales, la gente no dispone de los medios para comprarlos y el médico de la única salita sanitaria se reparte entre El Cruce y El Fondo arribando a cada zona cada quince días, si es que el camino no se encuentra anegado por lluvias.

Los padres, si bien desean fervientemente que sus hijos aprendan hablar el castellano, generalmente no pueden ocuparse de su escolarización. Incluso

14 Foley (1996) expone varias de las explicaciones sociolingüísticas del silencio de los aborígenes, como ser que el silencio Mesquaki es una construcción cultural de su identidad, un juego con la imagen negativa del "indio silencioso". 
muchas veces delegan en la escuela grandes responsabilidades. Una madre de la escuela $\mathrm{C}$ me explicaba que su hija de 12 años fuma, bebe y se ausenta varios días de su casa, pero que ella no la puede controlar pues es madre soltera, tiene cinco hijos y debe trabajar todo el día; entonces cuestiona a la escuela por no cuidar de su hija y evitar sus excesos. Otra madre de la misma escuela se quejaba de la modalidad de jornada completa pues ella necesita que su hijo le ayude por la tarde trabajando. Durante la época de cosecha los niños colaboran con sus familias y se ausentan de la escuela. Muchas familias poseen como único sustento el ingreso de \$ 150 del "Plan Trabajar"; con ello se deben mantener familias muy numerosas; en consecuencia los niños llegan a la escuela mal vestidos, mal alimentados y sin útiles. La partida de útiles que envía el gobierno resulta altamente insuficiente. Los maestros no les dan tarea a los niños pues dicen que los cuadernos no regresan, ellos afirman que la mayoría no posee un lugar "cómodo" para hacer sus deberes. Muchos de los jóvenes entrevistados me aseguraron no haber podido terminar el Colegio Polimodal pues las exigencias materiales del Colegio, como ser hojas, carpetas, mapas, fotocopias, etc., son mayores que las de la escuela, resultándoles imposible a sus familias seguir costeándoles la educación.

Las escuelas también sufren las consecuencias de la crisis económica. Los maestros deben comprar las tizas y borradores y, dado que los niños no cuentan ni con libros ni con el dinero suficiente para sacar fotocopias, los docentes se encargan de escribir tarjetas a mano para cada niño o sacar las fotocopias. En algunas escuelas deben comprar los elementos de limpieza del baño e incluso turnarse para limpiarlo. También han llegado a comprar ventiladores para las aulas, dado que las temperaturas son muy altas y los techos son de chapa. Cuando llueve, en muchos casos, deben recorrer caminando una distancia tal que les lleva más de dos horas llegar a la escuela. Las instalaciones edilicias se encuentran bastante abandonadas. Cabe aquí volver a hacer la distinción según la zona. La escuela $\mathrm{B}$, con siete aulas, según los docentes posee inutilizable su instalación eléctrica original pues el techo de chapa se encuentra electrificado al estar en contacto con cables. ${ }^{15} \mathrm{La}$

\footnotetext{
15 Hace poco los alumnos de un colegio privado de Buenos Aires, quienes visitan la zona para colaborar con estas escuelas, instalaron algunos cables nuevos.
}

escuela A, en cambio cuenta con instalaciones sencillas que funcionan correctamente, en las aulas hay electricidad y ventiladores de techo pero tuvieron que romper algunas paredes pues había panales de avispas que atacaban frecuentemente a los niños. Las instalaciones de la escuela $\mathrm{C}$ en general son amplias pero la escuela en sí se encuentra muy mal mantenida (Figura 2). Las paredes poseen también panales de avispas, los sanitarios se encuentran inutilizables pues el pozo cloacal de los mismos está lleno y los desechos se observan por el piso.

Según una madre, los niños pisan descalzos las deposiciones y así entran a las aulas.

Ninguna de estas escuelas posee agua corriente ni gas. El contraste es muy marcado entre las escuelas de la Colonia y la del pueblo. La escuela D cuenta con todos los servicios y el estado de las instalaciones edilicias es excelente. Otro factor a tener en cuenta son las distancias que muchas veces existen entre las escuelas y las viviendas. No existe ningún transporte público salvo unos coches privados, los denominados "remises" que resultan inaccesibles para ellos por sus costos. Hasta aquí, la descripción de uno de los factores, el económico, que funciona inevitablemente como obstáculo del proceso escolar.

En segundo término, se encuentra otro factor fundamental: la connivencia del Sistema Educativo y la política. La denuncia sobre una fuerte presencia del poder político en todas las esferas de la vida pública surgió recurrentemente dentro y fuera de la Colonia, incluso en los medios de comunicación. Al ser una localidad pequeña las presiones y alianzas políticas poseen un alto grado de

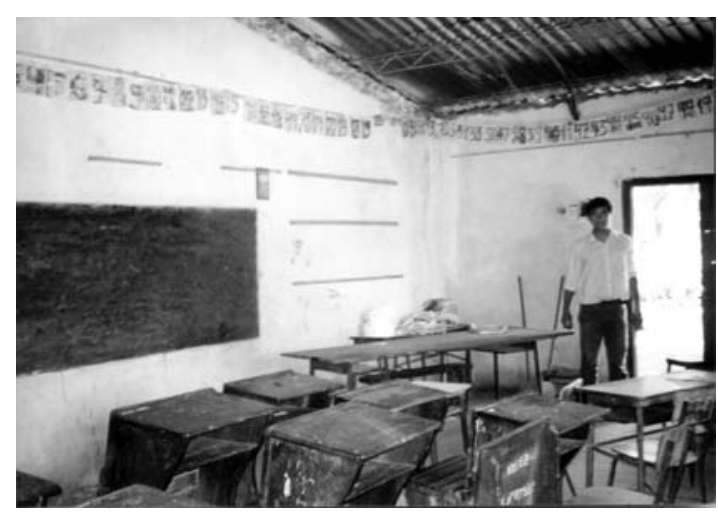

Figura 2. Aula escuela C. 
visibilidad social, situación poco cotidiana para un habitante de una gran ciudad. Mis interlocutores toba comentan que se observan los autos lujosos de los funcionarios en las casas de los dirigentes políticos aborígenes y que todos saben cuándo una persona está trabajando en la campaña de un candidato político. Incluso me aseguraron que por ser un año electoral esperan que arribe, como siempre, la caravana de candidatos junto a todas sus promesas y ofrecimientos de beneficios personales que nunca cumplirán. En lo que respecta al sistema educativo específicamente, es un criterio generalizado tanto en el pueblo como en la Colonia que los cargos educativos son asignados políticamente. La directora, Mirta, de la escuela A me comentó que su candidatura como concejal del partido opositor le costó el traslado a una escuela muy retirada y que luego de varios años logró regresar "por derecha" a su puesto como directora de dicha escuela; varios habitantes de la Colonia me narraron lo mismo. La directora de la escuela $\mathrm{D}$, Rosa, me comentaba que cuando el plantel docente, luego de no percibir varios meses sus haberes, decidió hacer una jornada de huelgas, los políticos se hacían presentes para presionar y ella les respondía que no podía modificar la decisión de los mismos. ${ }^{16}$ En la escuela $\mathrm{C}$ luego de destituir a la antigua directora por denuncias hechas por los padres por supuestos hurtos de la comida del comedor escolar, se asignó una directora de la ciudad de Clorinda, quien fue trasladada a los pocos días de asumir su cargo. En su reemplazo se nombró como directora a una maestra jardinera de la escuela. Los padres sospechan que dicho nombramiento fue el resultado de una maniobra política. Bourdieu ha denunciado este tipo de connivencia entre el Sistema Educativo y el Sistema Político. Según el teórico francés, es fundamental conocer los principios de selección para ingresar al campo, en este caso el educativo, pues los mismos no responden a un criterio que considera el mérito y el talento. De este modo el sistema educativo, al reproducir las jerarquías sociales en las jerarquías académicas, legitima el orden social.

Un tercer factor que agrava aún más el aprendizaje de los niños es el estado del sistema educativo

16 En el despacho de la directora se encuentra un retrato de ella junto al gobernador Gildo Insfrán, probablemente al finalizar las obras de remodelación de la escuela. A su vez hay un afiche del gobernador en la cocina de la escuela. en la zona y la falta de preparación de los docentes y directores para trabajar en escuelas de modalidad aborigen. Es muy común escuchar a los docentes quejarse de que el Magisterio no los ha preparado en absoluto para enseñar a los niños toba. Frente a una suplencia que se produce en una de las escuelas de "modalidad aborigen" los docentes sin experiencia laboral acuden y reciben un gran impacto por ser prácticamente su primer contacto con niños aborígenes. Luego de tres años pueden lograr la titularidad, una vez que ella se produce resulta muy difícil trabajar en una escuela de "modalidad común", pues deberían empezar por una suplencia nuevamente. Ninguno de los maestros entrevistados aprendió a hablar la lengua toba, y desconocen las características de su cosmovisión. La ley Integral del Aborigen 425, que se sancionó en 1984 en la provincia de Formosa establece la formación de docentes aborígenes para las escuelas de modalidad aborigen. Sin embargo, sólo existen tres maestros auxiliares aborígenes en toda la comunidad y su formación es muy limitada. En 1982 la directora de la escuela $\mathrm{C}$, de entonces, convocó a tres jóvenes aborígenes que habían terminado su escuela de Educación Básica para que trabajaran en la escuela y para ello los envió a estudiar a Formosa capital durante un mes. A partir de dicho año los tres maestros auxiliares se desempeñan en los dos niveles del "aprestamiento" (Nivel Inicial) y en el $1^{\mathrm{er}}$ año de la E.G.B., pero lejos de cumplir con la función pedagógica esencial como establece dicha ley; su función es la de "traducir" a la lengua toba las explicaciones de la maestra titular del grado. Por otra parte, la falta de asignación de cargos de maestros especiales deteriora la calidad de la enseñanza pues son los maestros de grado quienes suelen hacerse cargo de las áreas especiales. Es así como en la escuela B un maestro de grado enseña folclore y en la escuela $\mathrm{C}$ el maestro de huerta da Educación Física; el maestro carpintero dicta folclore y una maestra de grado enseña música por la tarde. Más allá de la buena voluntad y formación de dichos docentes, los niños no pueden recibir la enseñanza por los maestros especiales correspondientes. Los contenidos del diseño curricular y la imposición exclusiva del idioma oficial no sólo dificultan el aprendizaje sino que no tienen en cuenta en absoluto la especificidad sociocultural toba. La mayoría de los docentes coinciden en que a los niños aborígenes les resulta muy difícil el primer ciclo y que generalmente repiten el $1^{\text {er }}$ año. Si se tiene en cuenta 
la falta de preparación de los maestros y auxiliares para acompañar a los niños aborígenes en su aprendizaje y lo difícil que les resulta a los alumnos aprender el idioma castellano y los contenidos impartidos, se puede comprender en dónde radica su dificultad. Rockwell (1996: 26) desarrolla la idea de que algunas escuelas pueden llegar a ser más permeables a la cultura del entorno que otras, resultando a veces menor la distancia que mantienen con su entorno social que con la burocracia educativa. En el caso de las escuelas de este asentamiento, sin embargo, los maestros poseen un desconocimiento total de la cultura toba, de su lengua y no hay ningún contenido o tema que haga referencia a dicha cultura. Salvo en el área de Ciencias Sociales cuando se estudia la historia de la provincia, y el 19 de abril, "Día del Aborigen", en que se realiza algún tipo de celebración. Una maestra me comentaba que los niños preguntan mucho cuando se hace referencia a la historia de la región. En dichas clases son muy curiosos: "les interesa porque se sienten protagonistas", sostenía. En estas escuelas el conocimiento local, penetra mínimamente en el currículum escolar. En un Encuentro Provincial que se llevó a cabo en el 2002 denominado "Educación, Pueblos Indígenas y Poder" organizado por S.U.T.E.B.A. ${ }^{17}$ y la Mesa de Pueblos Originarios, Luis Pincén, profesor mapuche de Ciencias Naturales, hizo referencia a la necesidad de la "pluriculturalidad" y para ello dio un ejemplo toba. "Para este pueblo el gritar y pegar equivale dentro de sus categorías a asesinar", afirmó. Luego propuso a los maestros imaginar cómo puede repercutir un grito de un docente en un niño toba, "el niño inevitablemente se siente amedrentado (amenazado) y calla", concluyó. Novaro (2002) investigó sobre el tratamiento que se hace de los aborígenes en las propuestas oficiales, editoriales y escolares. Los contenidos escolares valorizan la construcción mítica de la Nación, su tendencia homogeneizadora no da cuenta de la diversidad cultural, tratan a los pueblos aborígenes como pueblos primitivos y congelados, el parámetro de comparación siempre resulta ser la civilización incuestionada y nunca reflexionan sobre el proceso histórico. En dicho artículo Novaro hace referencia a la contradicción del discurso de los docentes que oscila entre un etnocentrismo claro,

17 Sindicato unido de trabajadores de la educación de Buenos Aires. cuando la presencia aborigen se considera una amenaza, y un relativismo que reivindica la diversidad cultural en momentos en que su presencia no representa un riesgo para la nación, como ser antes de la Conquista de América y en la actualidad. En varias entrevistas noté miradas contradictorias con respecto a los aborígenes en un mismo discurso. Recuerdo, por ejemplo, el relato del bibliotecario:

\section{“(...) No podemos pretender que rindan como} nuestros chicos. Debería haber un programa especial. (...) Por problemas de lengua ellos piensan en toba y tienen que traducir al castellano. (...) En las escuelas los currículum deberían ser diferentes, no nivelar para abajo pues no serviría. Los contenidos deberían respetar sus intereses, su lengua... (...) A ellos les hace bien que vayan evolucionando, no sé si el término es pertinente. Que lleguen a ser integrales. Pero nosotros somos los que debemos acostumbrarnos".

La enseñanza exclusiva del castellano es un tema central. Es imprescindible tener en cuenta que las familias toba hablan en su lengua nativa. Tanto la ley provincial 424, anteriormente mencionada, como la Ley Nacional 23.302 sobre Política Indígena y Apoyo a las Comunidades Aborígenes de 1985, y la Ley Federal de Educación de 1994 establecen que en las comunidades aborígenes la enseñanza deberá ser bilingüe. ${ }^{18} \mathrm{La}$ enseñanza en las escuelas de toda la provincia varía según la región, en el oeste de la provincia desde hace muchos años se imparte una educación bilingüe; sin embargo, los alumnos toba del este de la provincia sólo aprenden el castellano. Una maestra me explicaba que su objetivo es "de a poquito ir sacándoles ese idioma. Vamos reemplazando sus palabritas por el castellano". En los relatos de los jóvenes toba es muy frecuente el comentario sobre sus primeras experiencias cuando las maestras sólo les hablaban en castellano y ellos no les

\footnotetext{
18 El artículo 16 de la Ley 23.302 dice: "La enseñanza que se imparte en las áreas de asentamiento de las comunidades indígenas asegurará los contenidos curriculares previstos en los planes comunes y, además, en el nivel primario se adoptará una modalidad de trabajo consistente en dividir el nivel en dos ciclos: en los tres primeros años, la enseñanza se impartirá con la lengua indígena materna correspondiente y se desarrollará como materia especial el idioma nacional; en los restantes años la enseñanza será bilingüe(...)".
} 
entendían. Algunos cuentan que se escapaban de las escuelas, otros que simplemente no comprendían por qué ellas se enojaban. Podría pensarse que para la escuela dicha lengua es el "obstáculo" a vencer. Un cartel que cuelga en una de las aulas, habla claramente de la "violencia simbólica" (Bourdieu 1998: 44) que se ejerce sobre los niños, en él se puede leer "La lengua castellana: Nuestra identidad nacional iberoamericana". La lengua toba (qom) queda absolutamente devaluada frente a la hegemónica. En el Polimodal, además, deben aprender inglés y portugués.

Una diferencia sustancial, que también habría que tener en cuenta, es su lógica de enseñanza/aprendizaje, basada principalmente en la demostración práctica del adulto y en la observación atenta del niño, pues difiere, en buena medida, de la del sistema escolar. Por ejemplo, en una ocasión fui al monte con el dueño de la casa donde me alojaba y su hijo Ezequiel para que nos enseñara, a Silvia Citro y a mí, las técnicas de "mariscar" (técnicas de caza, recolección y pesca). Cada vez que nos quería explicar algo realizaba una demostración práctica, como ser construir un camuflaje de hojas para cazar ñandú o acostar a alguien en el piso y simular todos los movimientos que los shamanes realizaban para extraer el veneno de una picadura de víbora. A propósito Gladis, maestra de la escuela A, me comentaba que a los niños les fascinan los experimentos y que son tan buenos observadores que luego describen el experimento con suma precisión. Probablemente, a los niños aborígenes les deben resultar muy tediosas las largas explicaciones teóricas que los maestros suelen dar en el pizarrón. Se podría tener en cuenta también que la mayor parte de su vida transcurre fuera de sus casas, al aire libre e intentar que los niños mantengan dentro de lo posible un mayor contacto con el exterior. Dentro de sus casas realizan muy pocas actividades, la mayor parte transcurren fuera de ellas. Por ejemplo, generalmente cocinan sobre leños sobre la tierra que los ubican cerca de la choza donde tienen los utensilios para cocinar y raramente lo hacen adentro, salvo aquellas familias que poseen cocina y que pueden comprar gas envasado; por la tarde el descanso inevitablemente se hace debajo de la sombra de algún árbol dadas las altas temperaturas. Suelen también comer afuera y cada uno en momentos diferentes. Es entendible entonces que los niños aborígenes se "desesperen" por salir al patio como afirman los docentes, y que las actividades que más les gusten sean las externas como ser el trabajo en la huerta y gimnasia. Por ello me sorprendió que en todas las escuelas la comida se sirviera en un aula, bajo el techo de chapa y con temperaturas que superan los $40^{\circ}$ centígrados. Al consultarle a una madre que servía el almuerzo en el comedor si alguna vez sacaban las mesas a la galería me respondió que no, pues se complicaría el servicio.

Finalmente, no puedo dejar de hacer mención a las instancias de discriminación que sufren los aborígenes en general. La discriminación puede surgir, por un lado, por el trato diferencial que reciben y por el otro, paradójicamente, por no tener en cuenta ciertas particularidades, por incorporarlos en políticas totalizadoras y homogeneizadoras que responden a los intereses hegemónicos. Pero circunscribiéndome específicamente al ámbito escolar, son muchas las denuncias de niños, jóvenes y adultos que hacen referencia al trato de inferioridad e inclusive al maltrato que reciben en la escuela por parte de maestros, directivos, compañeros e incluso padres de compañeros. Lamentablemente los casos son múltiples: desde una maestra, que al no hallar un objeto de su cartera, hizo desnudar a todos los niños y niñas en el aula para encontrar al responsable, pasando por la vicedirectora que le prohibía a sus propios hijos juntarse con aborígenes, hasta compañeritos que se quejan de los alumnos aborígenes diciendo: “¿Para qué vienen?, van a llenar de piojos", etc. Cabe aclarar, sin embargo, que el maltrato no es una actitud generalizada, aunque sí frecuente.

\section{Conjunto de respuestas y estrategias planteadas por los sujetos}

Ante las diversas trabas con las que los niños toba deben enfrentarse durante su vida escolar y teniendo en cuenta su posición de exclusión tanto política como económica y social, cabe preguntarse cuál es la respuesta de parte de los aborígenes, ya sea individual o social. Durante mi estadía en la comunidad pude registrar algunas estrategias que distintas familias adoptan con respecto a los obstáculos ya analizados. Por ejemplo, frente a la marcada diferencia entre las escuelas de la comunidad y la del pueblo dos madres aborígenes han decidido enviar a sus niños a la escuela del pueblo, aceptando el riesgo de que sus hijos puedan sentirse incómodos por hallarse entre criollos. Sin embargo, ambas se animaron y hoy cuentan que están felices de la educación y trato que 
sus hijos reciben y afirman que cuando sus otros hijos crezcan también irán a dicha escuela. Cabe aclarar que a ambas les queda más cerca la escuela B. Los padres en general consideran fundamental que sus hijos aprendan a manejar la lengua oficial pues saben que de ello dependerá la posibilidad de encontrar alguna salida laboral. Reconocen las ventajas concretas de poseer dicho "capital lingüístico" (Bourdieu 1990: 146). Es por ello que muchos, sobre todo los de la zona de El Cruce, se dirigen hacia una localidad fuera de la Colonia cuando sus hijos son pequeños para que aprendan el castellano y su cultura. Incluso muchos no les hablan en la lengua toba, para que no hablen mal el castellano. Pérsida me contaba que a su hija Daiana, de seis años, siempre le hablaron el castellano, pues "si no se iba a trabar" y afirma que "prefiero mejor que se quede con el castellano". La diferencia con la gente de El Fondo es que allí no poseen los medios para viajar fuera de la zona y tampoco manejan bien el castellano, por ello se quejan mucho de que la escuela no les enseñe el idioma. Lo que muchos padres de la escuela $\mathrm{C}$ hacen es enviar a sus hijos a la escuela B, aunque les quede lejos. Algunas madres me contaron que mandan a los niños los primeros años a esa escuela, hasta que aprenden a manejar el idioma, otras que están tratando de conseguir una bicicleta para que el viaje no se les haga tan pesado. Finalmente, con relación a la directora asignada en la escuela $\mathrm{C}$ y sospechada de favoritismo político, los aborígenes han ejercido gran resistencia en las diversas reuniones de padres, incluso han intentado pegarle según ellos.

Una vez analizadas las actitudes que las familias toba toman en el marco de su hogar con respecto a la situación educativa de sus hijos, interesa también saber cómo actúan o responden en la propia escuela frente a los demás sujetos sociales. Probablemente, la escuela sea la única institución de la zona donde se interrelaciona en forma permanente una importante cantidad de criollos y aborígenes de diferentes edades. La posición que los diversos agentes sociales ocupan configura las fuerzas de los mismos.

Tomo el espacio del comedor como epifenómeno representativo del funcionamiento de fuerzas dentro del campo educativo (Figura 3). Los padres aborígenes se nuclean en la Cooperadora para ejercer un control y una demanda concreta con relación al comedor escolar. Dicho espacio de poder

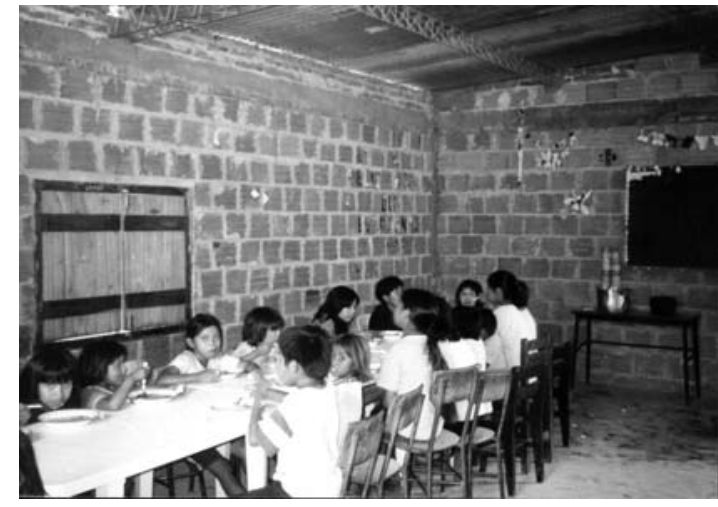

Figura 3. Comedor de escuela B.

se encuentra legitimado por el sistema educativo. De hecho es el único lugar donde pueden interceder dentro de la escuela, pues poco pueden objetar acerca de una educación que, como "arbitrariedad cultural" (Bourdieu 1998: 45) representativa de la clase dominante, no manejan. La profesora de lengua me comentaba que nunca asisten a las reuniones de padres, que pasan al otro día a retirar los boletines y que cuando se les hace algún comentario sobre una dificultad de sus hijos "aceptan todo pero no pueden hacer nada porque están en las mismas condiciones que sus hijos". El comedor se constituye como un campo de disputa permanente entre los diversos actores; las sospechas, alianzas y enfrentamientos giran siempre alrededor de dicho espacio. Es muy frecuente escuchar a los padres de los niños denunciar, incluso ante instituciones oficiales, que los maestros y directoras se llevan la comida a sus casas, que se quedan con parte del monto asignado para la compra de mercaderías o que las cocineras primero sirven a los niños blancos. Llegan incluso a cambiar a sus hijos de escuela cuando consideran que la comida en otra escuela es mejor. ${ }^{19} \mathrm{~A}$ su vez los maestros afirman que siempre hay discu-

19 Un día en la escuela $\mathrm{C}$ observé que una de las jefas de hogar arrojó la galleta que estaba comiendo a un perro y luego comentó algo a otra mujer que no pude entender pues lo hizo en su lengua. Cuando regresaba con la maestra aborigen ella me dijo que las galletas se encontraban agusanadas pues las habían comprado el mes anterior. A los dos días se siguieron sirviendo galletas y cuando pregunté si eran las mismas me dijeron que aquellas habían sido puestas en otro costado del estante. Antes de las comidas hacen rezar a los niños la siguiente frase: "Gracias Dios mío por el agua y por el pan. Gracias Dios mío por todo lo que nos das". Los niños juntan los restos de sus platos y los depositan en recipientes para llevárselos a sus casas. 
siones y que los padres se quejan mucho por el tipo de comida y que preferirían que la cocinera fuese aborigen. También dicen que deben controlar las despensas pues sino los aborígenes se llevan la mercadería.

Es interesante analizar cómo reaccionó la comunidad educativa y específicamente cada actor social ante los representantes ministeriales frente a las nuevas disposiciones que impedían que los niños retiraran la comida para llevársela a sus casas, pues el gobierno quería asegurarse que fueran los niños los que se beneficiaran con el alimento. La medida fue muy combatida por toda la comunidad escolar. Hubo reuniones antes del comienzo del receso escolar donde asistieron tanto los padres, los maestros, directoras como el supervisor y discutieron todos juntos las medidas. Los padres alegaban que en enero al mediodía hace demasiado calor como para que los niños se trasladen hacia las escuelas, que en muchos casos quedan muy lejos, en cambio preferían que uno de los niños retirara la comida para el resto de sus hermanos como venían haciéndolo hasta ese momento. Los maestros y directoras tampoco estaban de acuerdo. Además los maestros se quejaban que eran muchos niños para ser cuidados sólo por el docente de turno, y de que debían asistir a la escuela durante sus vacaciones. Incluso negociaban entre ellos el monto de dinero para ser reemplazos los días que les tocaba la guardia. Según una de las directoras la resistencia de sus colegas y de los maestros dependía del grado de compromiso político que tuvieran. Los padres en su totalidad se oponían pero se manifestaron muy poco, nuevamente hay que tener en cuenta el alto grado de oficialidad de dicha reunión. Cuando la presión fue externa la comunidad se unió para resistir la medida, fortalecidos por su conocimiento local de las características de la Colonia, pero cada uno con la fuerza que su posición en el campo les otorga.

\section{Reflexiones finales}

Al llegar a la Colonia aborigen donde realizaría el trabajo de campo, mi mochila estaba cargada de diversas teorías dispuestas a entrar en acción en cuanto yo lo requiriera. Si bien poseía alguna sospecha sobre cuál podría ser la más indicada, dado que ya había visitado la zona con anterioridad, procuré acercarme al campo lo más receptiva posible. Fue así cómo la realidad del lugar a través de la observación y de las diversas entre- vistas me fue llevando a tener en cuenta, también, ciertas dimensiones, instituciones y sujetos que si bien no se vinculaban en forma exclusiva con las escuelas, la atravesaban y actuaban obstaculizando la escolaridad de los niños toba. Me refiero al contexto socioeconómico en el que se encuentra la Colonia y a las relaciones personales que se establecen con los factores de poder de la zona, por nombrar algunos. El haberme circunscrito a un estudio micro, como ser el de la escuela y sus actores inmediatos, hubiera dejado de lado gran parte de las causas de la deserción escolar toba. La "perspectiva relacional" bourdieuana, su mirada atenta a las correspondencias entre las posiciones de los agentes y el campo de poder, en cambio, me resultó una herramienta valiosa.

En una sociedad tan verticalista como la formoseña donde, en la base de la pirámide social se encuentran los grupos aborígenes, el acortamiento de la distancia al vértice se impone como una necesidad básica para lograr las condiciones mínimas de subsistencia. Dicha realidad fomenta el surgimiento de "relaciones vasalláticas" entre los poderosos y los marginados. Es así como el "clientelismo político" impera en la zona y conlleva a la búsqueda de soluciones individuales. La distancia al centro de poder, que se ubica en la ciudad de Formosa, y las consecuencias socioeconómicas que se desprenden, se manifiestan también en la situación particular de cada escuela.

Dentro de la localidad estudiada, el centro del poder es el pueblo, de ahí las comodidades y el buen nivel educativo de la escuela $\mathrm{D}$, ubicándose en la peor de las desigualdades sociales la escuela $\mathrm{C}$, y su comunidad, de la zona de El Fondo.

No obstante, no se puede desdeñar la acción de los sujetos, que, si bien se encuentran muy limitados en su accionar, buscan el modo de que sus hijos no sean víctimas de un sistema que tiende a reproducir las diferencias sociales. ${ }^{20}$ Como ya se ha visto, tanto los maestros como las familias abo-

20 Una fuerte preocupación y descontento por la situación política en que se encuentran existe en la comunidad. En una de las escuelas, un grupo de padres me comentaba la impotencia que sienten frente al poder político y a la falta de posibilidades de ser representados por un aborigen dadas las trabas burocráticas que les presentan, por ello están asistiendo a las charlas que les ofrece un abogado para comenzar a conocer sus derechos, aunque reconocen que el "clientelismo político" los divide fuertemente. 
rígenes despliegan diversas estrategias. Dentro de la escuela, específicamente en el comedor, los padres toba sostienen una presencia enérgica y, en el ámbito privado, aquellos padres que manejan el idioma hablan en castellano a sus hijos desde pequeños, o migran de las escuelas y/o zonas siempre en dirección hacia el centro hegemónico.

Lejos aún se encuentran estos grupos aborígenes de Formosa de instalar discusiones, tales como las que los dirigentes de los pueblos mapuches de la Patagonia sostienen sobre la educación bilingüe e intercultural. Estos denuncian que los programas de educación intercultural responden a reformas de corte neoliberal que intentan folclorizar a los pueblos originarios sin atender las cuestiones de fondo, como ser la exclusión que vienen padeciendo. Proponen que se replantee la educación bilingüe e intercultural en términos de "etnoeducación", debiendo ser los propios aborígenes los protagonistas del proceso educativo. En el marco del contexto de la comunidad toba analizada, por un lado no se han generado políticas indigenistas que puedan convertirse en voces portadoras de reivindicaciones culturales y lingüísticas y por el otro cuando las posibilidades aparentes de obtener algún beneficio socioeconómico se vinculan con la adquisición del "capital lingüístico" que imparte la escuela occidental, dichas reivindicaciones parecen quedar postergadas.

Agradecimientos Quiero agradecer especialmente a la familia aborigen Velázquez quien me alojó por segunda vez en su casa y colaboró pacientemente conmigo, y a Silvia Citro quien no sólo hizo posible mi acercamiento a la comunidad, sino que generosamente responde a mis múltiples consultas.

\section{REFERENCIAS CITADAS}

BOURDIEU, P., 1990. Sociología y cultura. Grijalbo, México D. F.

BOURDIEU, P. y L. WACQUANT, 1995. Respuestas. Por una antropología reflexiva. Grijalbo, México D. F.

BOURDIEU, P. y J. C. PASSERON, 1998. La reproducción - Elementos para una teoría del sistema de enseñanza, Fontamara, México D. F.

CITRO, S., 2001 Ms. Conversión y procesos de diversificación en la religiosidad de los toba del Chaco argentino. Ponencia presentada a la XXVI Conferencia de la Sociedad Internacional de Sociología de las Religiones (SISR). 20 al 24 de agosto del 2001, Ixtapan de la Sal.

CORDEU, E., 1984. Notas sobre la dinámica religiosa Toba Pilaga. En Suplemento Antropológico XIX (1): 187-235.

FOLEY, D., 1996. El indio silencioso como una producción cultural. En The cultural production of the educated person. State University of New York Press, Nueva York.
MILLER, E., 1979. Armonía y disonancia en una sociedad. Los Tobas argentinos. Siglo XXI, México D. F.

NOVARO, G., 2002. "Indios", “Aborígenes" y "Pueblos Originarios". Sobre el cambio de conceptos y la continuidad de las concepciones escolares. VII Jornadas Regionales de Investigación en Humanidades y Ciencias Sociales. Jujuy.

ROCKWELL, E., 1996. La dinámica cultural en la escuela. En Hacia un currículum cultural: Un enfoque vygotskiano, Alvarez, A. y P. del Río (Eds), Madrid.

TRINCHERO, H., 2000. Los dominios del demonio. Civilización y barbarie en las fronteras de la nación. El Chaco Central. Eudeba, Buenos Aires.

WRIGHT, P., 1988. Tradición y aculturación en una organización socioreligiosa toba contemporánea. En Cristianismo y Sociedad 95: 71-87.

1990. Crisis, enfermedad y poder en la Iglesia Cuadrangular toba. En Cristianismo y Sociedad 95: 15-37. 